\title{
Elulugu folkloristlikust vaatepunktist ${ }^{1}$
}

\author{
Tiiu Jaago \\ Tartu Ülikooli kultuuriteaduste instituudi \\ eesti ja võrdleva rahvaluule osakonna dotsent \\ tiiu.jaago@ut.ee
}

\begin{abstract}
Teesid: Tänapäeva teaduses on elulood interdistsiplinaarse uurimise allikaks. Samas lähtutakse eluloouurimises märkimisväärselt ka erialadest: uurimiseks kasutatakse erialati välja kujunenud teooriaid ja töövõtteid, mida omakorda edasi arendatakse. Artiklis tutvustatakse (oma)elulooliste juttude uurimise kujunemist Eesti folkloristika näitel. Ühtlasi arutletakse folkloristliku eluloouurimise paigutumist interdistsiplinaarsel teadusväljal.
\end{abstract}

Märksõnad: eesti folkloristika ajalugu, elulugu, rahvaluule, teemajutustus

Elulood on tõsielule tuginevad jutustused, mille tegelasteks on jutustaja ja tema lähikondlased. Folkloristikas kasutatakse eluloo mõistet pigem harva, ent seda küllalt avaras tähenduses. "Eluloost" esiletulevam ja pigem tõsielulist või eluloolist jutustamist hõlmav on Satu Apo (1995) kasutusele võetud teemakirjutamise mõistest edasi arendatud "teemajutustus". Ühtlasi rõhutatakse teemajututuse seotust nii küsimustiku kui ka muude tekstiloomet mõjutavate teguritega (Jaago 2008: 99-104; vrd nt sama suulise eluloo intervjuu kohta Palmenfelt 2006). Ka kirjandusteaduses on kasutusel mitmeid tekstiliike hõlmav koondmõiste "elulookirjutus" (Hollo 2017). ${ }^{2}$ Eesti etnoloogias käsitletakse elulugusid mälu ja meenutamise uurimisega seoses, mistõttu žanrimääratlusest enam tulevad esile uurimisviisiga seotud meetodid ja mõisted, näiteks "biograafiline meetod", "kollektiivne mälu" (Kõresaar 2003). On ilmne, et elulugu kui allikmaterjal on avar ja avatud mitmele teadusalale. See annab põhjust kõnelda eluloouurimise interdistsiplinaarsusest. Samas tekib aga küsimus eluloouurimise erialasest spetsiifikast: mis iseloomustab folkloristlikku eluloouurimist ja mida see õieti hõlmab? Et vastata neile küsimustele, võrdlen esmalt folkloristlikku eluloouurimist lähialadel tehtavaga. Seejärel vaatlen rahvaluuleteaduses toimunud arenguid, mis on seostatavad tänapäevase eluloouurimisega. 


\section{Elulugude uurimise interdistsiplinaarsus}

Tiina Kirss on oma töödes korduvalt ja mitmeplaaniliselt käsitlenud elulugude žanrilist hübriidust, mis teeb eluloost interdistsiplinaarse allikteksti (vt nt Kirss 2003: 218-222, 237-244; 2006: 620 jj; 2017). Igal erialal on eluloost võimalus leida see tasand, mis avaneb just selle eriala meetoditega kõige enam. Folkloristika ja kirjandusteaduse kokkupuutepunktiks on eluloo vaatlemine jutustusena, eristab aga see, milliste tekstiliikide hulka elulugu paigutatakse. Kirjandusteaduses kõneldakse selliste žanrite omavahelistest seostest nagu autobiograafia ja mälestused, omaeluloolisus ilukirjanduses, päevikud ja kirjavahetus, kvalitatiivsed eluloointervjuud jm kirjutamise (või kirjakultuuri kuuluvad) žanrid (vt nt Hollo 2017: 577). Rahvaluuleuurimises seostuvad elulood aga näiteks isikujuttude, nii suuliste kui ka kirjalike teemajutustuste jm tõsielulugudega, mida tavapäraselt ei esitata kirjanduslikel eesmärkidel. Folkloristlikus jutu-uurimises pööratakse tähelepanu mitte ainult jutustusele endale, vaid ennekõike esitusele: kuna iga fikseeritud elulugu käsitletakse sama loo ühe variandina, siis küsitakse, kuidas mõjutas esitus vaadeldava teksti tunnuseid. ${ }^{3}$

Esitus toob uurija tähelepanukeskmesse jutustamise aja. Jutustamise aeg on esil ka etnoloogilises eluloouurimises, kus ühelt poolt koondub tähelepanu teatud ajajärgu meenutamisviisidele ja teiselt poolt nende põhjustele, mis lähtuvad avalikest aruteludest. ${ }^{4}$ Elulood - nii arhiivi saadetud kirjalikud jutustused kui ka uurija tehtud biograafilised intervjuud - paigutuvad neis uurimustes selliste tekstide hulka nagu publitseeritud mälestused ja elulood, poliitikute kõned, dokumentaalfilmid, muuseumi väljapanekud jms (Jõesalu 2017: 234). Eluloo paigutamine erinevate tekstiliikide väljale aitab mõista ka erinevusi, mida etnoloogiline ja folkloristlik eluloouurimine pakub. Näiteks analüüsib Ene Kõresaar monograafias "Elu ideoloogiad" elulugusid, mis on kirjutatud 1990. aastatel (need pärinevad Eesti elulugude kogust, EKLA f 350). Ta küsib, kuidas neis, nõukogude-järgsel ajal jutustatud lugudes tõlgendatakse 1940. aastate sündmusi Eestis. Ta näeb neis tõlgendustes "katkestuse domineerimist ja järjepidevuse puudumist poliitilises, ühiskondlikus, kultuurilises, kogemuslikus jne plaanis“(Kõresaar 2005: 69). Folkloristlikus elulooanalüüsis tuleb katkestusest enam esile järjepidevus (Jaago 2014: 1075-1079). Etnoloogiliste ja folkloristlike uurimistulemuste erisuunalisus (katkestus - järjepidevus) 20. sajandi ajaloosündmustest jutustamise uurimises ajendas seda teemat eesti elulugude näitel täpsemalt vaatlema. Võrreldes stalinlike vangilaagrite teema esitusi 1980. aastate lõpust 1990. aastate lõpuni selgus, et vangilaagriteema esitus selle kümnendi jooksul ei muutunud, kusjuures neis kirjeldustes on ilmne katkestuse ja järjepidevuse omavaheline põimumine. Küll aga erinesid elulugude 
kirjutamisaega esindavad seisukohad ja kommentaarid: varasemates lugudes tuli katkestuse teema selgemalt esile kui kümnendi lõpus (Jaago 2016).

Eelöeldu osutab folkloristika eripärale lähtuda lugude jutustamisest, samal ajal kui etnoloogide tähelepanu on pööratud hoiakutele ühiskonnas. Seega ei ole folkloristlikud ja etnoloogilised lähenemisviisid vastuolulised, vaid osutavad võimalusele saada samadest allikatest eriilmelist teavet.

Eesti eluloouurimused on tänapäeva teadusele omaselt pihustunud üksikuteks artikliteks, mis on avaldatud eri keeltes mitmetes kohtades. Uurimisviise ja -võimalusi koondava ülevaate võib siiski leida esmalt kahe ajakirja erinumbrist: üks neist on Leena Kurvet-Käosaare (2010c) koostatud Methise teemanumber "Omaelulookirjutus eesti kultuuriloos", teine Maarja Hollo ja Leena Kurvet-Käosaare (2017) koostatud Keele ja Kirjanduse teemanumber "Elulood žanripiiridel". Kuigi mõlemad teemanumbrid esindavad uurimusi mitmelt erialalt, on need koostatud kirjandusteaduslikust vaatepunktist ning käsitluse keskne mõiste on “(oma)elulookirjutus”.

Eesti eluloouurimusi koondava teise näitena tuleks käsitleda kahte ingliskeelset artiklikogumikku: kirjandusteadlase Tiina Kirsi, etnoloog Ene Kõresaare ja sotsioloog Marju Lauristini (2004) koostöös valminud artiklite ja elulugude kogumikku "She Who Remembers, Survives" ja etnoloog Ene Kõresaare (2011) koostatud "Soldiers of Memory". Ka need kogumikud esindavad mitme eriala vaadet elulugude uurimisele: autorite seas on nii kirjandus- kui ajalooteadlasi, sotsiolooge kui folkloriste ja etnolooge. Erinevus eelkirjeldatud ajakirjade teemanumbritega seisneb aga selles, et kogumike teoreetiline raam ei lähtu ühest erialast (kõige enam on neis esil interdistsiplinaarse mälu-uurimise mõisted ja seisukohad, mis kõikidele artiklitele siiski ei laiene). Ajakirjanumbritega võrreldes on kogumike eripäraks veel see, et kõik autorid kasutavad sama allikaliiki - analüüsitavad (ja kogumikes ka avaldatud) tekstid pärinevad Eesti elulugude kogust (EKLA f 350). Kogumike koostamisega seotult toimus lugude analüüsi teemalisi seminare. Sellest koostööst kasvas välja Tartu Ülikooli humanitaaria magistriõppe interdistsiplinaarne kursus "Omaeluloolisus 20. sajandi uurimises" (2015; 2017).

Kõnesolev mitme eriala esindajate koostöö Eesti elulugude kogu kujundamisel ja uurimisel on märkimisväärselt mõjutanud minu arusaamist elulugude uurimise distsiplinaarsusest ja interdistsiplinaarsusest: milliseid küsimusi ühe või teise eriala esindaja eluloole kui allikale esitab; millise konteksti ta eluloo tõlgenduseks loob; millist lisamaterjali ta selleks vajab; kus on näiteks folkloristliku elulootõlgenduse mõistmise ja mõistmatuse piir? Need on küsimused, mis on kaasa aidanud ka käesoleva teemanumbri koostamisele.

Elulooteemalisi uurimusi koondavaid ajakirjanumbreid ja artiklikogumikke saab Eestis vaadelda seega kahel suunal. Ühelt poolt lähtumine eriala spet- 
siifikast, kus kasutatakse erinevaid allikmaterjale. Teiselt poolt sama allikmaterjali (Eesti elulugude kogu, EKLA f 350) uurimine erinevate teadusalade vaatevinklist. Mõistagi võivad autorid neid allikaid kombineerida või teha viiteid mõlemale suunale: kasutades oma erialal väljakujunenud arhiivide või välitöömaterjale, viitavad nad ka Eesti elulugude kogu tekstidele või vastupidi.

\section{Folkloristika erialade vahelise koostöö maastikul}

Erinevate erialade kokkupuude eluloouurimises ärgitab küsima, kuidas siin mõistetakse folkloristika erijooni. Kokkuvõtvalt toob selle esile Tiina Kirss (2017), osutades, et ajaloouurimises kerkib enam esile küsimus tõest, kirjandusteaduse huvikeskmesse koonduvad loo poeetika ja eneseesitluse viisid. Folkloristika osa kirjeldab ta seoses pärimusainese kasutamisega eluloojutustuses (Kirss 2017: 898; vrd Kirss 2013). Tiina Kirss tugineb siin James V. Wertchi mõistele "tekstuaalne ressurss" ja ühtlasi selle vastele "kultuuriline ressurss", mis pärineb Vieda Skultansi läti elulugude alastest uurimustest. Skultans kasutab mõistet nii rahvaluule kui muude jutustajate seas tuttavate tekstide (nt koolis õpitu) tsiteerimisega seoses. Kirss teeb kokkuvõtte: "Kirjandusteaduslik elulugude käsitlus on pidanud tähelepanuväärseks ning köitvaks uurimisobjektiks elulugude narratiivsust ning kultuurilisi/tekstuaalseid ressursse, millele lugu tugineb ja mille abil kollektiivsete mälumustritega suhestub" (Kirss 2017: 898). Kui kirjakultuurist lähtuva vaate järgi saab rahvaluuletekste eluloos tsiteerida, siis folkloristlikust vaatepunktist tuleks tsiteerimise asemel vaadata motiivi või teema aktualiseerumist ühes või teises seoses (vt nt rahvusvaheliselt levinud rahvajutumotiivide indekseid). Samuti on kasutatud nn mentaalse teksti mõistet, mille kaudu on võimalik kirjeldada tekstiloomet kui protsessi. Mentaalne tekst (Honko 1996: 4) on esituseelselt jutustaja mõtetes olemasolev teadmine nii loost, selle jutustamise viisidest kui ka esitusest. Sellest lähtuvalt koondub folkloristide huvi mitte niivõrd valmis jutule, kuivõrd lugude jutustamisele: kuidas ajalooliselt ja regionaalselt rohkem või vähem levinud motiivid konkreetses olukorras meenuvad ja esile kerkivad; mis tähendusi need jutustamise ajas ja ruumis ning lugude esitajate ja kuulajate seas omandavad (vt nt Jaago 2001a; Kalmre 2007).

Arhiivi saadetud kaastööde puhul, nagu seda on ka Eesti elulugude kogu, lähtuvad folkloristid ühelt poolt võimalusest piiritleda pikas sidusas loos väiksemaid omaette terviklikke tekste. Sellist uurimisviisi rakendab näiteks Ingrid Rüütel artiklis "Laulud eesti elulugudes", kus ta vaatleb (rahva)laulude esinemist Eesti elulugude kogu tekstides (Rüütel 2003). Teisalt aga juhivad nad tähelepanu sellele, et loo üksikosi vaadeldakse tervikloo seisukohast. Nii näeb 
Jyrki Pöysä fraasides “mäletan üht korda, kui ...”, "pärast seda on olnud nii, et ..." jutustaja võtet siduda väikesed lood tervikjutustusega. Ta teeb kokkuvõtte: "Selliste lausetega osutab jutustaja ühe (või mitme) loo omadusele olla ühtse terviku iseseisvaks üksuseks", mis omakorda näitab, "et konkreetset tervikteksti (ehk jutustuse üht varianti) saab tunnetuslikult liigendada eraldiseisvateks osadeks" (Pöysä 2009 [2006]: 50).

Jyrki Pöysä väites on kaks folkloristliku jutu-uurimise seisukohast olulist viidet. Esmalt jutu käsitlemine variandina (mitte viimistletud valmis loona, mille uusesitus oleks kas koopia või redaktsioon). Teiseks esituse vaatlemine tervikuna, hoolimata sellest, et tekstiosadena võib selles märgata omaette terviklikke väikelugusid. Seega ei piirdu tänapäeva folkloristid pikemast jutustusest pisilugude (laulude, lühivormide, pärimuslike motiivide) välja noppimise ja pelgalt nende tekstilõikude analüüsiga, sest neid üksikosi vaadeldakse kooskõlas terviktekstiga. Ilmselt teeb olukorra keeruliseks see, et elulugu on pigem kirjaliku kui suulise jutustamise žanr. Samas märkavad folkloristid ka suuliste esituste korral (näiteks välitöödel uurija ja jutustaja vestlusvoos), et erinevaid suulise pärimuse žanre raamistab eluloolisus. Ühe skeemi suulise eluloo-jutustamise žanrite põimust ehk "traditsioonisidusast eluloolisest jutustamisest" on oma välitöökogemusele tuginedes pakkunud Taisto Raudalainen (2001: 62). ${ }^{5}$

Seega: eluloo tekstuaalne kontekst interdistsiplinaarsel ajajärgul eeldab eluloo kui jutustuse sobitumist seni erialaspetsiifilisteks peetud uurimisallikatega. Tervikteksti analüüsis on ka folkloristikas (sarnaselt ajaloo- ja kirjandusteaduslikule eluloouurimisele) oluline roll tekstuaalsel raamistikul ehk intertekstuaalsusel. Kui ajalooteadustes on siin oma osa ametlikel dokumentidel(vt nt Palamets 1989; Rahi-Tamm 2011) ja kirjandusteaduses kirjutamise žanritel, siis folkloristikas on selleks pärimusliku jutustamise žanrid. Sellegi poolest iseloomustab eluloouurimist oma eriala seisukohast tavatute allikate kasutuselevõtt. Oma uurimistöös olen Eesti eluloo kogu tekstide ja klassikaliste pärimuslugude (näiteks asustus- ja isikulugude) kõrval kokku puutunud ajaloo uurimisest välja kasvanud "ajaloolise traditsiooniga" ja Eesti Rahva Muuseumi teemaküsitluste materjalidega. ${ }^{6}$

\section{Elulugu folkloristikas}

Võib küsida, millal ja mis tingimustel sai elulugudest folkloriste huvitav jutuliik. Takistas ju indiviidikeskse eluloo paigutumist folkloristliku uurimise peateele pikaaegne eeldus jutusüžeede stereotüüpsusest ja pärimuse kollektiivsusest. Individuaalse kogemuse kesksed lood tulevad folkloristide huvivälja tasahaaval. Eesti folkloristikas tugineb see vaade folkloristliku teooria ja tööpraktika muu- 
tustele 1930. aastatel, mil Eesti Rahvaluule Arhiivi uurijad hakkasid üha enam huvi tundma esitusolukordade ja traditsiooni kui elukogemuse edasiandmise vastu (vt Hiiemäe 2003: 55-57). Samal ajal tulevad folkloristide huviväljale pajatused (esialgse nimetusega isikuloolised jutustused), mis suunavad enam tähelepanu pöörama (tõsielu)tegelastele (Loorits 2000 [1927]; Hiiemäe 1978: 10).

Isikulooliste jutustuste teema toob folkloristikasse Oskar Loorits 1927. aastal avaldatud artiklis "Vägilase prototüüpe" (Loorits 2000). ${ }^{7}$ Rahvajutu folkloristlikku liigitusse paigutab selle iseseisva jutuliigina 1950. aastate muistendi-alastes töödes Eduard Laugaste, pakkudes mõisteks "pajatus". Rahvaluuleõpikus avab Laugaste pajatuse mõiste järgmiselt: "Pajatus on seotud elava või kunagi elanud isiku üksiku elujuhtumusega või jutustab mingit kõneainet andnud lokaalsest sündmusest" (Laugaste 1975: 272). Teemat arendas süvitsi edasi Mall Hiiemäe (1978). Üks olulisi aspekte tema töös on vaadelda lugude kujunemist jutustamiste käigus, küsides, kuidas teadmine konkreetsest (sündmusest ja isikust) loo edasijutustamisel folkloriseerub (Hiiemäe 1978: 38). Hiiemäe käsitlust lugude folkloriseerumisest on rakendanud Kalle Voolaid Georg Lurichist kõneleva pärimuse näitel (Voolaid 2001). Rahvusvahelisest folkloristikast on analoogilises tähenduses, ent tänapäeva folkloori nähtusena 1970. aastatel esile kerkinud "isiku(kogemus)jutt" (Stahl a-ta; Titon 1980: 289; Dégh 2003 [1989]: 10). ${ }^{8}$ Rahvaluule seotust eluloolisusega on märgatud ja esile toodud, tuginedes nii folkloristlike välitööde kogemustele kui ka antropoloogia-alaste tööde mõjule kultuuriteadustes 1970., eriti 1980. aastatel (vt ülevaadet sellest Dégh 2003 [1989], vrd Titon 1980). Nii Jeff Todd Titon kui ka Linda Dégh näevad folkloristliku eluloo uurimise eripära eluloo käsitlemist jutustusena. Ent see aspekt tuleb nendes sõnavõttudes esile kultuuriantropoloogilise ja suulise ajaloo uurimise, mitte (ilu)kirjanduse kontekstis.

Hoolimata pikast kujunemisteest (mis on folkloristid elulugude juurde juhatanud) on isikukesksete lugude uurimise huvikeskmes enne 1990. aastate folkloristikat eelistatavalt jutusüžee, mitte jutustaja individuaalne ja isikupärane kogemus. Ka eelmainitud Linda Dégh seob eluloo mõiste rahvajutu üldiste tunnustega: "Sarnaselt rahvajuttudele esitavad ka elulood täielikust elukäigust ainult kilde [---]. Tavaline elulugu, nagu rahvajuttki, keskendub kõrghetkedele - positiivsetele või negatiivsetele tegudele ja nende tagajärgedele, kusjuures mõlemad on lõpetamata jutustused. Mõlemat tüüpi jutustused lõpevad niipea, kui karjäärialased eesmärgid on saavutatud ja tegutsemismotivatsioon kadunud" (Dégh 2003 [1989]: 12). Selles sedastuses on ilmne viide variaablusele: oma lugu saab jutustada korduvalt ja uuest vaatenurgast, tehes valikuid neist sündmustest, mis loo jutustamisloogikaga kõige paremini sobivad. Samas toob autor esile karjääriteema kui omaeluloo jutustamise selgroo. Selle aspektiga seoses saab ta eluloo jutustamise siduda traditsiooniliste (kogukonnas 
toimivate ja domineerivate) hoiakutega: "Nii kavandatuna on elulood mudelid, mis esindavad oma säilimise eest võitleva ühiskonna status quod" (Dégh 2003 [1989]: 14). Võib näha, kuidas üksikisiku asemel on esil süžee, mis haakub kogukonna alalhoidlikkusest lähtuvate valikutega. Analoogiline on olukord ka mina-jutustuste sidumisega varem teaduses kinnistunud rahvajutuliikidega. Sellisteks jutuliikideks on memoraat ja kronikaat: ka nende puhul tuleb esile küll jutustaja enda (mitte vahendatud) kogemus, kuid jutustaja-minast olulisem on loo seotus üleloomuliku või argielulise ja ajaloolise nähtusega (vt nt Kuusi 1980: 40). Samas seob Matti Kuusi kronikaadid lähiajaloosündmusi meenutavate mälestustega, osutades sellele, et folkloristikas tuleks lähtuda jutustamisest (mitte pelgalt tekstist): "Tõsiuskne folklorist jääb suulise ajaloo allikate (muistitietoaineiston) juures kahtlema: kas tegemist on tõepoolest pärimusega? Kust me teame, et neid jutte on tõepoolest räägitud?" (Kuusi 1980: 45). Ühtlasi näitab ta, et mitmed kronikaadina käsitletavad jutud on pakkunud ainest ilukirjandusele. Nii Déghi kui Kuusi käsitlusest aimdub üks 20. sajandi lõpu ja tänapäeva folkloristika (mälestusi uurivate teadusalade) tunnusjooni: seni erialaspetsiifilistena käsitletud allikmaterjalid hakkavad ületama erialapiire. Näiteks Matti Kuusi sõnavõtus oli see piiriületus seotud rahvaluule ühe žanri kronikaadi (lähiminevikus toimunud sündmustest mina-vormis jutustamine) ja suulise ajaloo ühisosaga. Mõistagi kaasnes see teaduse interdistsiplinaarse ajajärgu kujunemisega.

20. sajandi viimase veerandi uurimispraktikast võib leida ka selliseid töid, mis otseselt osutavad pärimuse ja (oma)eluloolisuse seotusele. Üheks selliseks on Juha Pentikäise käsitlus Marina Takala mõttemaailmast ja selle seotusest tema elukäigu ning pärimuslugudega (Pentikäinen 1971: 85-111). 1990. aastal avaldab vana rahvalaulu uurija Senni Timonen artikli, milles ta käsitleb omaeluloolisust ingeri lauludes, mida laulikud on öelnud olevat nende enda elust (Timonen 1990: 189). Sellist (uut) lähenemisviisi vanale rahvalaulule võimaldas folkloristika klassikaliste uurimisviiside ühitamine feministlike uurimissuundadega. Eesti, õigemini setu rahvalaulu näitel on omaeluloolisust analüüsinud Anne Vabarna pärimuse näitel Andreas Kalkun (2004).

Lisaks uurimisviiside piiripealsusele tuleb neist näidetest esile küsimus eluloo fiktsionaalsusest: mil määral saab põimida omaeluloolisse jutustusse niisuguseid motiive, mida ratsionaalse mõtlemise kohaselt ei seostata tõsieluga. Näiteks läti suulise ajaloo ja eluloouurija Māra Zirnīte imestab, kuidas üks liivi jutustaja, 1902. aastal sündinud Lizete Švanberga põimib traditsioonilisi muistendimotiive oma minevikumälestustesse: "Lizete jutustab muistendit, põimides sinna oma naabri - Daviṇi peremehe - ja lõpus toetub veel ka veterinaararsti öeldule, et sinised lehmad on tõepoolest olemas olnud, sest praeguseks on nad "otsa saanud"” (Zirnīte 2001: 28). Folklorist selliste seoste üle eriti ei 
üllatu. Näiteks Jeff Todd Titon on oma 1980. aastal ilmunud artiklis seostanud elulood (“inimese lugu enda elust”) folkloristliku jutu-uurimisega esmalt loo jutustaja ja tema kuulaja mõjuseoste kaudu (elulugu ei ole mitte lihtsalt jutustus, vaid esitus, kus loo kuulajaskonnal on oma roll teksti kujunemises); teiseks nimelt selle kaudu, et oma loo jutustamine võimaldab fiktsionaalsust, millest tulenevalt "eluloo keel ei ole ajaloo[st jutustamise] keel" (Titon 1980: 278-279). Teisalt võib ju mõista, et selle liivi jutustaja elus ja mõttemaailmas ei eristunudki pärimus ja argielu sellisel viisil, nagu seda eeldaks tänapäeva ratsionaalse mõtlemisega inimene. Ilmneb, kuidas ühelt poolt muutuvad uurimisviisid, sobitades oma eriala traditsioonilised võtted uute lähenemisviisidega, teisalt muutuvad ka jutustamisviisid, mis omakorda suunavad uurijaid uurima ka varemalt fikseeritud tekste kui omaaegseid jutustamisviise.

20. sajandi lõpu Eesti folkloristikas on täheldatav, et eluloo-uurimine paigutub mingi üldisema uurimisviisi alla. Näiteks 1996. aastast ilmuma hakanud folkloristikaajakirjas Mäetagused on ilmunud kolm teemanumbrit, milles sisaldub rohkesti elulugudel põhinevaid uurimusi, ent rõhk neis asetseb kas rahvajutu-uurimisel (Mäetagused 23, 2003) või pärimusliku ajaloo uurimisel (Mäetagused 43, 2009 ja 56, 2014). Samas ilmneb, kuidas folkloristliku teooria uuenemine (rahvaluule käsitlemine esituse, tegevuse, suhtlusviisina) ja huvi tänapäeva folkloori vastu 1980. aastatel loob pinnase mitte ainult elulooliste tekstide uurimiseks vaid ka mitmete tänapäeval oluliste ühiskondlike probleemide käsitlemiseks, näiteks migratsioon, mitmekultuuriline keskkond, tänapäeva meedia, kultuuripiirid.

21. sajandil on eesti folkloristid märkimisväärselt enam hakanud kirjutama selliste materjalide põhjal, mis on arhiivides küll alal olnud, ent mille vastu varem ei ole sel viisil huvi tuntud. Näiteks Katre Kikas käsitleb epistolaarseid ja omaeluloolisi tekste, mille saatsid Jakob Hurdale tema vabatahtlikud kaastöölised-rahvaluulekogujad (Kikas 2017a; 2017b).

Kui Hurda kirjasaatjate päritolu ja biograafiliste andmete kohta on folkloristid varemgi huvi tundnud, siis Katre Kikase uurimused avavad kirjasaatjate enda vaatepunkti oma tegevusele ja sellele, kuidas nad ise end tolleaegsesse ühiskonda paigutavad. ${ }^{9}$ Ühtlasi ilmneb, et kirjasaatjad ise kasutavad eluloo mõistet (Kikas 2017b: 585). Janika Oras käsitleb rahvalauliku eluloo kirjapanekut kohaliku teise lauliku tööna (Oras 2017). Nii Kikase kui ka Orase käsitlusi saab vaadelda "rahvaliku elulookirjutuse näitena", nagu sedastab Maarja Hollo (2017: 580).

Omaette valdkonnana eluloouurimisest võib esile tuua Anu Korbi, Astrid Tuisu ja Aivar Jürgensoni töid Venemaa eestlaste lugudest ning Mare Kõiva artiklit Rootsi eestlaste lugudest. Nende tööde tunnuseks on tuginemine välitöömaterjalidele. Siinkohal vaid mõned näited. Aivar Jürgenson vaatleb eesti ja vene ajaloopildi konflikti, mis lähtub Teise maailmasõja tõlgendustest ja 


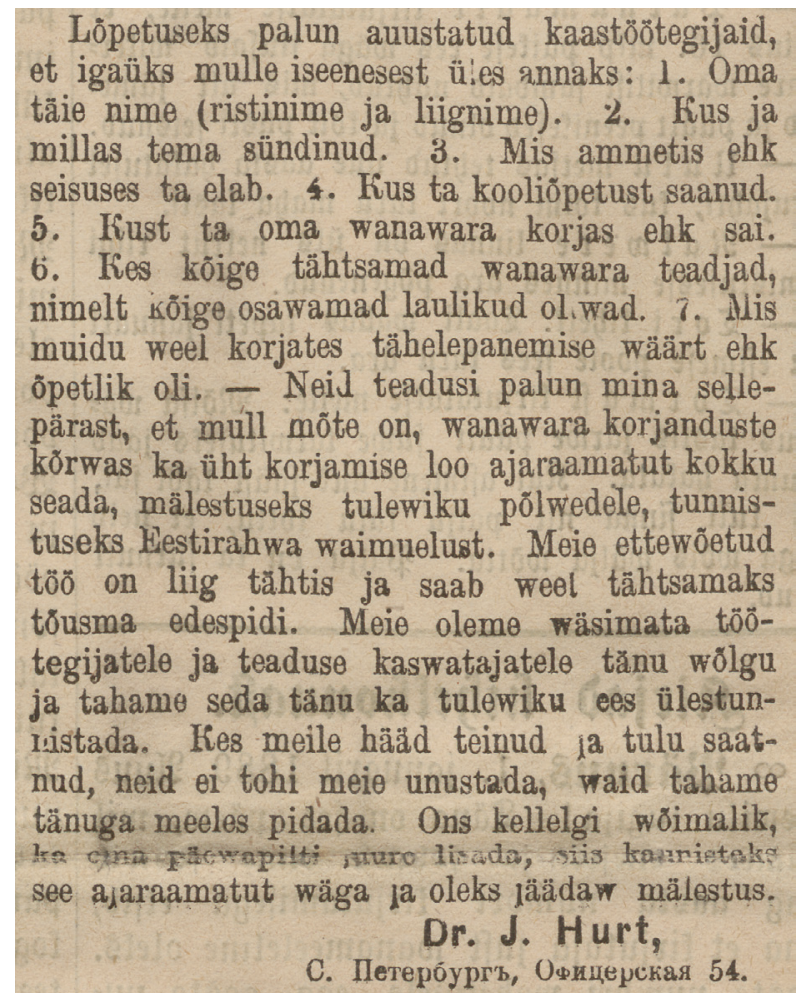

Jakob Hurda elulooteemalised küsimused oma kaastöölistele. Palve eesmärk oli koostada "korjamise loo ajaraamat” (Hurt 1889).

kulmineerus seoses pronkssõdurisündmustega 2007. aastal. Kahe eluloointervjuu võrdluses koorub välja tõdemus, kuidas omaeluloolised seigad mõjutavad rändlejate kohanemisprotsessi Eestis ning etniliste stereotüüpide võimu individuaalse ajaloopildi kujunemises (Jürgenson 2008). Astrid Tuisk (2011) ja Anu Korb (2011) analüüsivad oma välitöömaterjalidele tuginedes Siberi eestlaste lugusid rändekogemusest, seda siis nii päritolulugudena kui ka oma elukogemusi vahendavate lugudena. Anu Korb on koostanud ja publitseerinud Venemaa eestlaste elulookogumikke (vt nt Korb 2010, 2014). Need lood on rahvaluulearhiivi laekunud nii välitööde kui ka kogumisvõistluste materjalina - uurija aastakümneid kestnud koostöös selle rahvarühmaga. Rootsieestlastega tehtud intervjuusid käsitlevas artiklis visandab Mare Kõiva domineerivad teemad, et sellelt pinnalt lähtudes arutleda nii ajalooliste sündmuste kui ka lugude (rahvusvahelise) stereotüüpsuse üle (Kõiva 2003). Kuna autori huvikeskmes on nimelt isikulood (mitte omaeluloolisus), tulevad järeldustes esile eluloolise jutustamise kogukondlikud aspektid. 


\section{Arhiiv, välitöö ja uurija folkloristlikus eluloouurimises}

Käesolevas kogumikus on kuus artiklit, mis peegeldavad folkloristliku eluloouurimise erinevaid võimalusi nii allikate valiku kui ka uurimisküsimuste esitamise poolest.

Katre Kikas jätkab varem ajakirjas Keel ja Kirjandus avaldatud teemadel, arutledes Jakob Hurda kirjasaatjate omaeluloo ehk rahvaliku elulookirjutuse üle. Autor toob esile nende tekstide paiknemise suulise kultuuri ja kirjakultuuri piirialal, ühtlasi märkides tekstikirjutuse otsest tõukumist Jakob Hurda rahvaluule kogumise aktsioonist.

Teoreetilise raami seisukohalt tuleb esile, et vaadeldavate elulookirjutiste puhul on tegemist mitmeplaaniliste, sageli ka mitmesse saadetisse jaotunud sõnumitega. Katre Kikas kasutab assamblaaži mõistet, et kirjeldada rahvaluulekogusid ja ühtlasi siduda rahvaluulekogud nende saatjate omaelulooliste sõnumitega. Nagu iga rahvaluulesaadetis koosnes erinevate pärimusžanrite reast, ja iga kirjasaatja võis oma kirjapanekud saata vähehaaval mitmes jaos ("järg tuleb"), nii on ka vaadeldavad omaeluloolised tekstid jaotunud mitmesse saadetisse ning sisaldavad erinevaid tekstistiile ja -viise. Ühtlasi rõhutab Katre Kikas vaadeldava omaelulookirjutuse loomisraami. Selleks on rahvaluule kogumise aktsioon, mida ka kaastöötajad ise tajusid üldrahvaliku ettevõtmisena: nendes omaeluloolistest tekstides avaldub kirjutajate arusaam endast selles aktsioonis.

Katre Kikase käsitlus põhineb küll üle saja aasta vanusel allikmaterjalil, ent avab sellest uue vaatenurga: kuidas kirjasaatjad ise oma elu lugu mõtestasid. Kahe kirjasaatja omaelulooliste tekstide näitel ilmnevad elulookirjutuse nii tekstilised eeskujud ja poeetilised valikud kui ka kirjutaja kogemusest lähtuv elutunnetus toonases ühiskonnas. Oma loo kirjutaja ei keskendu üksnes enda isikule ja oma loole, vaid ta vaatleb end ja oma käekäiku üldisemas ühiskondlikus plaanis. Siin artiklis toodud näidete puhul on muuhulgas arutlusel väljarändaja staatus ja kohanemine diasporaa kogukonnas.

Anu Korbi artiklis tuleb samuti jutuks diasporaa-eestlaste vaade elule. Suuremas osas välitöö-materjalidele, ent ka arhiiviainesele tuginedes tutvustab Anu Korb Venemaal sündinud ja Eestisse naasnud eestlaste pärimuse näitel üht võimalikku viisi, kuidas folkloristid oma klassikalisi uurimisvõtteid kasutades siiski eluloolisuse juurde jõuavad. Küsides klassikaliste rahvaluuleliikide kohta (nt rahvaarstimise, kommete kohta), saadakse näitelugude varal jälile nimelt eluloolistele seikadele. Tuleb ilmsiks, kuidas pärimusteave ei seisa eraldi muust elust ja kogemusest (vastupidiselt sellele, kuidas analüütilistest kategooriatest lähtuvad ülevaateteosed meie teadmisi kipuvad kujundama). 
Anu Korb osutab muutustele folkloristlikes arusaamades (nt kollektiivsus versus individuaalsus) ja selle ilmnemist rahvaluuleuurija päevatöös. Artiklis vaadeldakse omaeluloolisust teemade kaupa, alustades päritolulugudest ja lõpetades eluringi sündmustega. Ka siinses artiklis tuleb kõneks omaelulooliste tekstide žanriline mitmekesisus. Anu Korbi käsitluse muudab aga eripäraseks see, et ta vaatleb Venemaa eestlaste lugude motiive Eesti Rahvaluule Arhiivi kogude taustal. Taas tuleb esile rahvaluuleuurimise üks erijooni - lugude variaabluse jälgimine. Küsimus ei seisne pelgalt samade motiivide kasutuses, vaid ka selles, kuidas üht või teist motiivi oma pärimusse on sulatatud. Näiteks, kuidas mõjutab mõisaaegse elu kirjeldusi see, et tegu on 19. sajandi lõpul või 20. sajandi alguses Eestist väljarännanute pärimusega? Üks pärimussõnumi mõjutegureid on see, kuidas oma rühmas kujundada kogukonna staatust ja ühiskondlikku positsiooni, teine aga see, kuidas kohaneti uute oludega. Nii moodustub neist lugudest kogukonna (või pere) pärimuslik ajalugu. Eluringi-sündmuste teema pakub enam teavet jutustajate enda elu ajal toimunust: neis põimub kogukonna tavade järgimine nõukogude aegse argieluga. Anu Korb näitab, et Venemaa eestlaste omaeluloolisus on tihedalt läbi põimunud kollektiivsete teadmiste ja toimingute ehk folklooriga.

Pikema aja vältel kujunenud traditsiooni, eluloolisuse ja folkloristlike välitööde põimumise teema tuleb esile ka Natalia Ermakovi artiklis. Oma välitöökogemusele tuginedes vaatleb ta esmalt uurija enda eluloo osa selles, kuidas ta pärimuse valdajatega kontakti saavutab. ${ }^{10}$ Teisalt käsitleb ta välitöödel talletatud itkejate omaeluloolisi esitusi. Artikli tuumaks on aga küsimus, kuidas tasakaalustub traditsioonis väljakujunenud vorm ühe isiku kordumatu sündmusega rahvaluule sellises žanris nagu itk. ${ }^{11}$ On ju itkud žanriliselt kindlapiirilised, seda nii teksti ülesehituse kui ka esitusega seotud reeglistiku poolest. Samas itketi alati konkreetse inimesega seotud sündmuste puhul, pidades silmas tema ja ta lähedaste suhteid. Kuidas itkeja seob traditsiooniomase poeetilise keele individuaalse situatiivse kontekstiga? Selles mõttes võib surma- ehk matuseitke vaadelda võrdluses teiste surmaga seotud tekstiliikidega nagu nekroloog vm järelehüüded. Kõigis neis on omad ajalooliselt välja kujunenud raamid, kuhu lahkunuga seotud sõnum paigutada. Ühelt poolt on itkemine elulooline sündmus, kuna see on seotud elu pöördepunktide või kriitiliste olukordadega (abiellumine, surm, sõtta minek). Teisalt on itk kultuuritekst, mis on sajandite vältel välja kujunenud ning mille rakenduseks otsitakse võimalusi ka siis, kui itkemine ei sobitu enam endisel viisil (eluloosündmusena) moodsasse elustiili. Natalia Ermakov näitab, kuidas itkeja omaeluloolisus on itkemisega seotud ka tänapäeval, kui itk kohandatakse kontsertesituseks. Biograafilisest vaatepunktist itkutekste analüüsides ilmneb, millised muutused on ühiskonnas toimunud ja kuidas inimesed on nendega toime tulnud. 
Tiiu Jaago artiklis analüüsitakse traumaatiliste kogemuste esitusi elulugudes. Lähemalt analüüsitakse kaht käsikirjalist eluloojutustust, mis pärinevad Eesti elulugude kogust (EKLA f 350). Üldisema tausta loovad neile samalaadsed arhiivitekstid (elulood, teemakirjutused) kui ka samade jutustajate teised esitused (esmalt välitöömaterjalid ja teiseks kirjalikud kaastööd Eesti Rahva Muuseumi korrespondentide vastuste arhiivist). Artikli tõukeks on aga küsimus, kuidas suhestub elulugudes (eluloolises teemajutustuses ja eluloointervjuus) traumaatilise kogemuse esitus traumateoreetiliste ${ }^{12}$ seisukohtadega. Teema on intrigeeriv, et mõista spontaanse jutustamise ja avalike hoiakute (olgu need vahendatud siis dokumentalistikas, kirjandusteostes, filmides, poliitilistes aruteludes vms) omavahelisi mõjuseoseid.

Andreas Kalkun kasutab oma uurimuseks folkloristi jaoks tavatut allikmaterjali, milleks on Rahvusarhiivis talletatavad kohtutoimikud. Tema uurimisteemaks on teatud laadi kogemus (homoseksuaalsus) 1920.-30. aastate Eesti ühiskonnas. Nagu Natalia Ermakovi artiklis itkude puhul, on ka siin tegemist kindlatüübilise tekstiliigi - kohtutoimikuga, mis avab biograafilise, mitte autobiograafilise vaate. Andreas Kalkuni käsitluses on tunnuslik, et ta ei keskendu niivõrd isikute homoseksuaalsuse kogemusele kuivõrd ühiskonnas käibivatele hoiakutele homoseksuaalsuse suhtes. Selle põhjuseks on mõistagi teema: homoseksuaalsus on kultuurides ja riikides olnud mitte ainult tabu, vaid ka kohtulikult karistatav, mistõttu omaeluloo avalikes esitustes seda esile ei ole toodud. Andreas Kalkuni käsitlus võimaldab ühe biograafilise aspekti kaudu vaadelda teema olulisust, ilmnemisviise ja hinnanguid omaaegsetes avalikes diskussioonides.

Astrid Tuisk tutvustab folkloristliku arhiivimaterjali üht loomisviisi - temaatilisi kogumisvõistlusi. Täpsemalt saab tema oma artikliks ainest 2013. aastal toimunud mänguteemalisest kogumisvõistlusest. Mängukirjeldused selles ainestikus tulid esile omaelulooliste meenutustena. Ühelt poolt paigutub nii ainese kogumisviis (pöördumine vabatahtlike kirjasaatjate-kaastööliste poole teatud teemal pärimusainese kogumiseks) kui ka materjali korrastamisviis (meenutustes esile toodud mängude paigutumine traditsiooniliste mängude hulka) klassikalist rahvaluuleuurimist. Samas sisaldub aga selles taas omaeluloolisus. Ilmneb, nagu Anu Korbi artikliski, kuidas varasemad uurimisviisid viivad folkloristi vältimatult kokku omaeluloolisuse uurimisega.

\section{Kokkuvõte}

Elulugu esineb rahvaluules hajutatult, mistõttu folkloristid eelistavad kõnelda omaeluloolisusest, teemajutustusest. Teisalt on see ala aga märkimisväärselt 
püsiv, mistõttu siin ei saa kõnelda "biograafilisest buumist" või “autobiograafiliste romaanide ja biograafiate jõulisest esiletungist" nagu 1990.-2000. aastate kirjanduses (Kõresaar 2005: 7; Hollo 2017: 578). Omaette küsimus on aga eluloolisuse esiletõus folkloristlikes uurimustes.

Ajalooliselt on folkloristika keskendunud pigem tõsielus olemas olnud üksikutele aspektidele kui indiviidi kogemusele sellest. Näiteks rahvameditsiini uurimisküsimuseks on olnud pigem haigused, ravivõtted, ravimtaimed jms, mitte haigeks olemise kogemus (vt nt Paal 2010). Asustusloo teemadest on taas esil pigem teave küla või kogukonna ajaloost kui individuaalne kogemus paiklikust eluviisist. Folkloristide huvi nihkumine individuaalse kogemuse suunas on toimunud tasahaaval kogu 20. sajandi vältel. ${ }^{13}$ Ühte etappi selles tähistab jutustajate, laulikute, rahvaarstide jms ning esitusolukordade uurimine. Tähelepanu keskmesse jõudis omaeluloolisus aga siis, kui humanitaarteadustes hakati keskenduma kultuuri kui terviku uurimisele. Ühtlasi iseloomustab seda perioodi interdistsiplinaarsus, olgu seda siis teadusalade vahelise koostööna, eriala seisukohast tavatute allikate kasutuselevõtuna või mitme eriala esindajate aruteludena sama laadi allikate analüüsil (vt interdistsiplinaarsuse kohta folkloristikas lähemalt Mäetagused 65, 2016). Viimast iseloomustab kirjandusteadlaste, sotsioloogide, ajaloolaste, etnoloogide ja folkloristide ühistöö Eesti elulugude koguga seoses.

Eesti elulugude kogu sai alguse 1980. aastate lõpul, ent selle loomise ja edendamise peamiseks viisiks on folkloristikas ja etnoloogias igapäevane arhiiviainese loomistava - temaatiliste kogumisvõistluste korraldamine. Kuigi küsitlusviisid ja -eesmärgid on Eesti Rahvaluule Arhiivi, Eesti Rahva Muuseumi ja elulugude kogu puhul mõnevõrra erinevad, seisneb ühisosa nii kirjutajate ringis ja nende arusaamises sellest kaastöövormist kui ka kirjalike tekstide loomusest. Nii sobivad erinevate arhiivide tekstid interdistsiplinaarseks uurimiseks üsna hästi. Folkloristide (ja etnoloogide) ellu kuulub loomuldasa ka välitöö, mille kohalolekut ka siin esitatavates artiklites küllaga kohtab.

\section{Kommentaarid}

1 Artikkel on seotud Eesti Haridus- ja Teadusministeeriumi rahastatava projektiga IUT 2-42 "Traditsioon, loovus ja ühiskond: vähemused ja alternatiivsed diskursused".

2 Ühelt poolt tuuakse uurimustes esile tekstiliikide piirid. Näiteks on jätkuvalt aktuaalne Philippe Lejeune 1970. aastatel esitatud autobiograafia määratlus, kus autobiograafia puhul on autor, jutustaja ja peategelane identsed ning jutustatav on seotud "isiksuse ajalooga" (Lejeune 2010 [1975]; vrd Kurvet-Käosaar 2010a: 225). Eesti kirjanduses viljeldavate žanrite "mälestused" ja "elulood" erinevust kirjeldab Rutt Hinrikus (2003: 173) peategelase ja loo sündmuste omavahelise positsiooni kaudu: eluloos on keskne jutustaja, mälestustes pigem tema ümber toimuv. Samal ajal võetakse kasutusele 
uusi mõisteid, mis sobivad tänapäevaste jutustamis- ja uurimisviisidega, näiteks “omaelulookirjutus" (Kurvet-Käosaar 2010b).

3 Näiteid sama jutustaja erinevatest esitustest ja jutustamise ajendite osast tekstiloomes (oma elust jutustamine vastusena vaba struktuuriga küsitlusele ja struktureeritud küsitlusele, jutustamine erinevale auditooriumile, suuline ja kirjalik jutustamine) vt nt Jaago 2008: 99-101; 2011; 2018: 40.

4 Etnoloogilise eluloouurimise kujunemine ei ole käesoleva artikli teemaks, sellegi poolest võib täheldada, et ka varasemates (1990. aastate lõpu, 2000. aastate alguse) uurimustes on eos olemas sama rõhk: miks 1990. aastatel jutustatud elulugudes tulevad esile just need teemad ja miks just sellistes toonides (vt nt Kõresaar 2001: 120; Anepaio 2003). Samas võib etnoloogide ja folkloristide varasemate tööde ühisosa leida ka ajastuomase argielu ja kogemuste kirjelduste uurimises (vt Mulla 2003; Kõresaar 2003: 67).

5 Taisto Raudalainen seob eluloolise jutustamisega nii kindlapiirilised kui ka jutustades kujunevad žanrid, alustades vaimulikest lauludest, memoraatidest ja unenäotõlgendustest, lõpetades kombestiku ja tavandipärimuse kirjeldustega. Ühtlasi osutab Raudalainen sellele, et nende lugude eluloolisus ilmneb esitusseostes, suhtlussituatsioonis, samas kui jutuloome aluseks on traditsioonis väljakujunenud struktuurid, olgu selleks siis žanrid, vormelid või nn "jutustamise grammatika" (Raudalainen 2001: 65).

6 "Ajalooline traditsioon" hõlmab küsitluskavast lähtuvaid minevikumeenutusi, mille rahvusvaheliseks paralleeliks on "suuline ajalugu" (Jaago 2018: 54-56). Suulise ajaloo (USA-s 1940. aastate lõpul alguse saanud oral history) uurimissuuna klassikaliseks allikmaterjaliks on ajaloolase ja intervjueeritava dialoogis sündinud suuline ajaloo intervjuu, mida käsitletakse kui kahe autori koostööd (shared authority) (vt Grele 2007: 13). Analoogiliselt käsitleb intervjuusid ja mälestusi ajaloolane Hillar Palamets (1989), kuigi tema ja USA-st lähtuv uurimistraditsioon kujunesid iseseisvalt ja paralleelselt. Eesti Rahva Muuseumi korrespondentide vastuste arhiivi materjalid lähtuvad samuti küsimustikest, mistõttu ka neis kaastöödes on rohkem või vähem alal küsimustiku ülesehitus. Samas ei kohustata jutustajat või kaastöölist küsitluskavast kuigi rangelt kinni pidama, mistõttu kohtab lihtvastuste (tean, ei tea, nii oli ...) kõrval ka vabamas vormis meenutusi, sh väljakujunenud jutte. Minu huvi nende materjalide kasutuselevõtus oli seotud tõsielulugude vaatlemisega rahvapärase minevikukäsitluse ehk ajaloopildi seisukohast, ning selle uurimisviisi nimetasin pärimuslikuks ajalooks (Jaago 2001b).

7 Oskar Loorits avaldab selles artiklis mh 17 biograafilist lugu. Näiteks nr 2 all "Soosare "Valla Ants". Soosaare vallas, Kolga-Jaanis, oli üks mees, keda rahvas üldiselt nimetas "valla Hans", sest ta hulkus valda mööda talust tallu ..." (Loorits 2000:14). Tema eesmärk oli visandada selliste lugude tegelaste tüüpjooned: millistel reaalelu tegelastel on potentsiaali saada rahvalugude kangelaseks.

8 Eesti folkloristidest on mõistet “isikujutt” omaelulooliste tekstide analüüsil rakendanud näiteks Mare Kõiva (2003).

9 Näiteks seab Rein Saukas (1970) oma uurimistöö (mille teemaks on Järvamaalt pärit Hurda kaastöölised ja nende saadetud rahvaluuleaines) üheks eesmärgiks "koguda võimaluse piirides uusi andmeid kaastööliste elu ja tegevuse kohta ning teha süntees sellest, mis siiamaani on teada" (Saukas 1970: 4). Saukas juhib tähelepanu Hurda huvile ja tähelepanelikkusele oma kaastööliste vastu, viidates muuhulgas Hurda 24. aruandele 1889. aastast, kus Hurt palub oma kaastöölistel saata vastused kuuele 
küsimusele: oma täisnimi, sünniaeg ja koht, amet ja seisus, "kust ta kooliõpetust saanud", kust kõige enam rahvaluulet üles kirjutas ning "kes on kõige osavamad vanavara teadjad" (Hurt 1889). Saukas keskendub oma käsitluses biograafilistele aspektidele, kuigi viitest allikmaterjalile ilmneb selle autobiograafilisus (vt nt Saukas 1970: 20-21).

${ }^{10}$ Välitöödel vestluspartneriga kontakti saavutamiseks vajalik eneseavamine ei ole folkloristidele üldiselt võõras. Siinkohal vaid üks - elulugudega - seotud näide: Triinu Ojamaal tuli nganassaani autobiograafilisi laule salvestades jutustada kohalikele laulikutele ka oma elulugu: "Ühes sellises situatsioonis vormis minu vestluspartner mu jutu lauluks. Viisi laenas ta oma isa laulust, teksti improviseeris ise. See jutustas minu tööst Ust-Avami külas ning minu perekoona elust "kaugel lõunas", kus Eesti nganassaanide ettekujutuse kohaselt asub" (Ojamaa 2003: 110).

${ }^{11}$ Mõrsjaitkude eluloolisust analüüsib ka Taisto Raudalainen (2001: 64-65), ent seda mitte niivõrd isiku kuivõrd kogukondliku rolli keskselt.

12 Traumateooria lähtub ühelt poolt holokausti, hiljem ka muude poliitiliste konfliktide ja looduskatastroofide kujutamisest, teisalt nende sündmuste tõlgendamisest tänapäevaste väärtushoiakute seisukohast (vt nt Kirss 2002; 2006: 617; Rothe 2011; Laanes 2017).

${ }^{13}$ Kusjuures huvi isikuloolisuse ja individuaalse kogemuse vastu on mõjutanud mitte ainult teaduses toimunud muutused, vaid ka muutused pärimusaineses, sh eluloolises jutustamises endas. Viimane omakorda peegeldab indiviidi ja kollektiivi (kogukonna, ühiskonna) omavaheliste suhete loomust: mil määral ja kuidas inimene eristab end oma keskkonnast; kuidas ta määratleb end oma kuuluvuse kaudu.

\section{Allikad}

EKLA f 350 - Eesti Elulugude kogu (alates 1989. aastast). Eesti Kirjandusmuuseum, Eesti Kultuurilooline Arhiiv.

\section{Kirjandus}

Anepaio, Terje 2003. Eesti mäletab!? Repressiooniteema retseptsioon Eesti ühiskonnas. Kõresaar, Ene \& Anepaio, Terje (toim). Mälu kui kultuuritegur: etnoloogilisi perspektiive. Studia Ethnologica Tartuensia 6. Tartu: Tartu Ülikooli Kirjastus, lk 206-230.

Apo, Satu 1995. Naisen väki. Tutkimuksia suomalaisen kansanomaisesta kultuurista ja ajattelusta. Helsingi: Hanki ja Jää.

Dégh, Linda 2003 [1989]. Ilu, jõukus ja võim. Naiste karjäärivõimalused rahvajuttudes, muinasjuttudes ja tänapäeva meedias. Mäetagused 23, lk 9-55 (doi: 10.7592/ MT2003.23.degh).

Grele, Ronald J. 2007. Reflections on the Practice of Oral History: Retrieving what we can from an earlier Critique. Suomen Antropologi. Journal of the Finnish Anthropological Society 4, lk 11-23 (http://oralhistoryseminar.pbworks.com/w/file/fetch/51790698/ Reflections\%20on\%20the\%20Practice\%20of\%20Oral\%20History.pdf-21. mai 2018). 
Hiiemäe, Mall 1978. Kodavere pajatused. Kujunemine ja koht rahvajututraditsioonis. Tallinn: Eesti Raamat.

Hiiemäe, Mall 2003. Eesti Rahvaluule Arhiivi rajaleidmised. Jaago, Tiiu \& Kõresaar, Ene (toim). Pärimus ja tõlgendus. Artikleid folkloristika ja etnoloogia teooria, meetodite ning uurimispraktika alalt. Tartu: Tartu Ülikooli Kirjastus, lk 50-60.

Hinrikus, Rutt 2003. Eesti elulugude kogu ja selle uurimise perspektiive. Krikmann, Arvo \& Olesk, Sirje (toim). Võim ja kultuur. Tartu: Eesti Kirjandusmuuseum, Eesti kultuuriloo ja folkloristika keskus, lk 171-213.

Hinrikus, Rutt 2010. Eesti autobiograafilise kirjutuse kujunemisest 18. sajandist Teise maailmasõjani. Leena Kurvet-Käosaar (koost). Methis 5-6. Omaelulookirjutus Eesti kultuuriloos, lk 20-37 (doi: 10.7592/methis.v4i5-6.516).

Honko, Lauri 1996. Epics along the Silk Roads: Mental Text, Performance, and Written Codification. Oral Tradition 11 (1), lk 1-17 (http://journal.oraltradition.org/issues/11i/ honko_intro-21. mai 2018).

Hollo, Maarja 2017. Elulood žanripiiridel. Saateks elulookirjutuse teemanumbrile. Keel ja Kirjandus 8-9, lk 577-583 (http://kjk.eki.ee/ee/issues/2017/8-9/957 - 21. mai 2018).

Hollo, Maarja \& Kurvet-Käosaar, Leena (koost) 2017. Keel ja Kirjandus 8-9. Elulood žanripiiridel.

Hurt, Jakob 1889. Kaheskümnes neljas aruanne. Eesti vanavara korjamisest ja keelemurrete uurimisest. Olevik $\mathrm{nr}$ 7, 13.02.1889, lk 1.

Jaago, Tiiu 2001a. Kuidas mõista pärimusjutu tõde? Anepaio, Terje \& Kõresaar, Ene (toim). Kultuur ja mälu. Studia Ethnologica Tartuensia 4. Tartu: Tartu Ülikooli Kirjastus, lk 227-243.

Jaago, Tiiu 2001b. Mis on "pärimuslik ajalugu”. Jaago, Tiiu (koost). Pärimuslik ajalugu. Tartu: Tartu Ülikooli Kirjastus, lk 7-15.

Jaago, Tiiu 2008. Ruumi kujutamine eluloos: küsimus tõsielujutustuse žanrist. Jaago, Tiiu \& Kõresaar, Ene (toim). Ruumi loomine. Artikleid keskkonna kujutamisest tekstides. Studia Ethnologia et Folkloristica Tartuensia 11. Tartu: Tartu Ülikooli Kirjastus, lk 99-119.

Jaago, Tiiu 2011. Maastik arhiivitekstides: lähiümbruse kirjeldamise žanrilised aspektid. Runnel, Pille \& Aljas, Agnes \& Kaalep, Tuuli \& Sikka, Toivo (toim). Eesti Rahva Muuseumi aastaraamat 54. Tartu: Eesti Rahva Muuseum, lk 92-113 (http://ojs.erm.ee/ index.php/ermer/article/view/76 - 21. mai 2018).

Jaago, Tiiu 2014. Discontinuity and Continuity in Representations of 20th Century Estonian History. Culture Unbound 6. Journal of Current Cultural Research: Thematic Section: Writing at Borders, lk 1071-1094 (doi: 10.3384/cu.2000.1525.1461071).

Jaago, Tiiu 2016. The Stalinist prison camp in Estonian life stories: depicting the past through continuity and discontinuity. Kannike, Anu \& Tasa, Monika (toim). The Dynamics of Cultural Borders. Approaches to Culture Theory 6. Tartu: Tartu University Press, lk 189-204.

Jaago, Tiiu 2018. Suulisus kirjakultuuri ajajärgul. Mäetagused 70, lk 39-66 (doi: 10.7592/ MT2018.70.jaago). 
Jõesalu, Kirsti 2017. Dynamics and tensions of remembrance in Post-Soviet Estonia: Late socialism in the making. Dissertationes Ethnologiae Universitatis Tartuensis 6. Tartu: Tartu Ülikooli Kirjastus (http://dspace.ut.ee/bitstream/handle/10062/55781/ joesalu_kirsti.pdf?sequence=1\&isAllowed=y - 21. mai 2018).

Jürgenson, Aivar 2008. Pronkssõduri sammude vaibuvas kajas. Siberist remigreerunud eestlaste kohanemisest Eestis: keel, stereotüübid, elulugu. Mäetagused 38, lk 75-100 (doi: MT2008.38/jyrgenson).

Kalkun, Andreas 2004. Anne Vabarna nina. Tõest ja valest seto naise autobiograafilistes lauludes. Sarv, Mari (toim). Regilaul - loodud või saadud? Tartu: Eesti Kirjandusmuuseum, Eesti Rahvaluule Arhiiv, lk 29-49.

Kalmre, Eda 2007. Hirm ja võõraviha sõjajärgses Tartus. Pärimuslooline uurimus kannibalistlikest kuulujuttudest. Tänapäeva folkloorist 7. Tartu: EKM Teaduskirjastus.

Kikas, Katre 2017a. Rahvaluulekogumine epistolaarses kontekstis. Keel ja Kirjandus 4, lk 272-290 (http://kjk.eki.ee/ee/issues/2017/4/912 - 22. mai 2018).

Kikas, Katre 2017b. Rahvaluulekogujate elulood Jakob Hurda rahvaluulekogus. Keel ja Kirjandus 8-9, lk 584-599 (http://kjk.eki.ee/ee/issues/2017/8-9/958 - 22. mai 2018).

Kirss, Tiina 2002. Põgenemine ja trauma. Looming 12, lk 1870-1880.

Kirss, Tiina 2003. Kolm eesti naist elulugudes. Krikmann, Arvo \& Olesk. Sirje (toim). Võim ja kultuur. Tartu: Eesti Kirjandusmuuseum, Eesti kultuuriloo ja folkloristika keskus, lk 215-245.

Kirss, Tiina 2006. Põgenemisteekonnad ja põgenemislood. Kirss, Tiina (koost). Rändlindude pesad. Eestlaste elulood võorrsil. Tartu: Eesti Kirjandusmuuseum, Toronto Ülikooli eesti õppetool, lk 611-646.

Kirss, Tiina 2013. Seeing Ghosts: Theorizing Haunting in Literary Texts. Rippl, Gabriele \& Schweighauser, Philipp \& Kirss, Tiina \& Sutrop, Margit \& Steffen, Therese (toim). Haunted Narratives. Life Writing in an Age of Trauma. Toronto: University of Toronto Press, lk 21-44.

Kirss, Tiina 2017. Sündmusküllased elulood. Erich Araku käsikiri. Keel ja Kirjandus 12, lk 897-915 (http://kjk.eki.ee/ee/issues/2017/12/992 - 22. mai 2018).

Kirss, Tiina \& Lauristin, Marju \& Kõresaar, Ene (toim) 2004. She Who Remembers, Survives: Interpreting Estonian Women's Post-Soviet Life Stories. Tartu: Tartu Ülikooli Kirjastus.

Korb, Anu (koost) 2010. Siberi eestlaste elud ja lood. Eesti asundused V. Tartu: EKM Teaduskirjastus.

Korb, Anu 2011. Siberi eestlaste mälestused emamaale naasmisest ja siin kohanemisest: isiklik ning kogukonna kogemus. Acta Historica Tallinnensia 17, lk 150-165 (doi: 10.3176/hist.2011.2.10).

Korb, Anu (koost) 2014. Eestlased Venemaal: elud ja lood. Eesti asundused VI. Tartu: EKM Teaduskirjastus.

Kuusi, Matti 1980. Kronikaateista. Pekka Laaksonen (toim). Kertojat ja kuulijat. Kalevalaseuran vuosikirja 60. Helsingi: Suomalaisen Kirjallisuuden Seura, lk 39-46. 
Kurvet-Käosaar, Leena 2010a. Saatesõna tõlkele. Kurvet-Käosaar, Leena (koost). Methis 5-6. Omaelulookirjutus Eesti kultuuriloos, lk 224-228 (doi: 10.7592/methis.v4i5-6.531).

Kurvet-Käosaar, Leena 2010b. Mõistete rägastikus: autobiograafiast omaelulookirjutuseni. Kurvet-Käosaar, Leena (koost). Methis 5-6. Omaelulookirjutus Eesti kultuuriloos, lk 7-19 (doi: 10.7592/methis.v4i5-6.514).

Kurvet-Käosaar, Leena 2010c (koost). Methis 5-6. Omaelulookirjutus Eesti kultuuriloos (http://www.methis.ee/arhiiv/methis-nr-5-juuni-2010 - 22. mai 2018).

Kõiva, Mare 2003. Lugu suurest lumesajust. Rootsieestlaste lood nõukogude Eestist. Mäetagused 23, lk 56-94 (doi:10.7592/MT2003.23.lumetorm1).

Kõresaar, Ene 2001. Nõukogude periood vanemate eestlaste elulugudes: probleeme ja tähelepanekuid. Jaago, Tiiu (toim). Pärimuslik ajalugu. Tartu: Tartu Ülikooli Kirjastus, lk 120-131.

Kõresaar, Ene 2003. Eluloolisest käsitlusviisist Eesti kultuuriteadustes. Jaago, Tiiu \& Kõresaar, Ene (toim). Pärimus ja tõlgendus. Artikleid folkloristika ja etnoloogia teooria, meetodite ning uurimispraktika alalt. Tartu: Tartu Ülikooli Kirjastus, lk 61-76.

Kõresaar, Ene 2005. Elu ideoloogiad. Kollektiivne mälu ja autobiograafiline minevikutõlgendus eestlaste elulugudes. Eesti Rahva Muuseumi sari 6. Tartu: Eesti Rahva Muuseum.

Kõresaar, Ene (koost) 2011. Soldiers of Memory: World War II and its Aftermath in Estonian Post-Soviet Life Stories. Amsterdam, New York: Rodopi.

Laanes, Eneken 2017. Trauma keelde tõlgitud. Kultuuriülesed mäluvormid eesti laagri- ja küüditamismälestustes. Keel ja Kirjandus 4, lk 241-257 (http://kjk.eki.ee/ee/ issues/2017/4/910 - 22. mai 2018).

Laugaste, Eduard 1975. Eesti rahvaluule. Tallinn: Valgus.

Lejeune, Philippe 2010 [1975]. Autobiograafiline leping. Methis 5-6. Kurvet-Käosaar, Leena (koost). Omaelulookirjutus Eesti kultuuriloos (artikli tõlkinud Tanel Leppsoo), lk 196-223 (doi: 10.7592/methis.v4i5-6.530).

Loorits, Oskar 2000 [1927]. Vägilase prototüüpe. Runnel, Hando (koost). Meie, eestlased. Eesti mõttelugu 35. Tartu: Ilmamaa, lk 9-45.

Mulla, Triin 2003. "Minu õnnelik-rahutu lapsepõlv": 1940. aastad eestlaste lapsepõlvemälestustes. Kõresaar, Ene \& Anepaio, Terje (toim). Mälu kui kultuuritegur: etnoloogilisi perspektiive. Studia Ethnologica Tartuensia 6. Tartu: Tartu Ülikooli Kirjastus, lk 91-123.

Mäetagused = Mäetagused (http://www.folklore.ee/tagused - 22. mai 2018)

Ojamaa, Triinu 2003. Elulugu muusikas: nganassaani autobiograafilise sisuga laulud. Mäetagused 23, lk 95-113 (doi: 10.7592/MT2003.23.ojamaa).

Oras, Janika 2017. Laulik jutustab laulikust. Marie Sepa elulooesitused suulise ja kirjaliku kultuuri piiril. Keel ja Kirjandus 8-9, lk 634-650 (http://kjk.eki.ee/ee/ issues/2017/8-9/961 - 22. mai 2018).

Paal, Piret 2010. Sissejuhatus. Inimene, tervis ja haigused kultuurilises perspektiivis. Paal, Piret (koost). Inimene, tervis ja haigused. Terviseteemaline artiklikogumik "Medica". Tänapäeva folkloorist 9. Tartu: EKM Teaduskirjastus, lk 9-31. 
Palamets, Hillar 1989. Mälestused helilindil Tartu Ülikooli ajaloo allikana. Rosenberg, Tiit (toim). Allikaõpetuslikke uurimusi. Eesti ajaloo küsimusi XI. Tartu Riikliku Ülikooli toimetised 851. Tartu: Tartu Riikliku Ülikool, lk 113-124.

Palmenfelt, Ulf 2006. The dark shadow of the un-mentioned event. Collapsing Taleworlds and Narrative Reparation. Kaivola-Bregenhøj, Annikka \& Klein, Barbo \& Palmenfelt, Ulf (toim). Narrating, Doing, Experiencing. Nordic Folkloristic Perspectives. Studia Fennica: Folkloristica 16. Helsingi: Finnish Literature Society, lk 101-116.

Pentikäinen, Juha 1971. Marina Takalon uskonto. Uskontoantropologinen tutkimus Helsingi: Suomalaisen Kirjallisuuden Seura.

Pöysä, Jyrki 2009 [2006]. Kogumisvõistlused pärimusliku ajaloo uurimises. Mäetagused 43, lk 39-60 (doi :10.7592/MT2009.43.poysa).

Rahi-Tamm, Aigi 2011. Aleksander Loog - Searching for One's Way: The Opportunities and Choices of Estonian Men during the Political Changes of the 1940s. Kõresaar, Ene (toim). Soldiers of Memory. World War II and Its Aftermath in Estonian Post-Soviet Life Stories. Amsterdam, New York: Rodopi, lk 235-262.

Raudalainen, Taisto 2001. Traditsioonisidus elulooline jutustamine: mäluainese etnopoeetiline tekstualiseerimine. Anepaio, Terje \& Kõresaar, Ene (toim). Kultuur ja mälu. Studia Ethnologica Tartuensia 4. Tartu: Tartu Ülikooli Kirjastus, lk 59-78.

Rothe, Anna 2011. Popular Trauma Culture. Selling the Pain of Others in the Mass Media. New Brunswick, New Jersey, London: Rutgers University Press.

Rüütel, Ingrid 2003. Laulud eesti elulugudes. Krikmann, Arvo \& Olesk, Sirje (toim). Võim ja kultuur. Tartu: Eesti Kirjandusmuuseum, Eesti kultuuriloo ja folkloristika keskus, lk 247-338.

Saukas, Rein 1970. Jakob Hurda kaastöölised Järvamaalt. Diplomitöö. Tartu Riiklik Ülikool, eesti kirjanduse ja rahvaluule kateeder. Käsikiri Tartu Ülikooli eesti ja võrdleva rahvaluule osakonnas, DT 87.

Stahl, Sandra K. D. [a-ta]. Jutud isiklikest kogemustest. VTK raamat (http://www. folklore.ee/seminar/pen.html - 22. mai 2018). [Tõlgitud: Stahl, Sandra K. D. 1986 [1983]. Personal Experience Stories. Dorson, Richard M. (toim). Handbook of American Folklore. Bloomington, Indiana University Press, lk 268-276.]

Zirnīte, Māra 2001. Identiteet liivlaste elulugudes. Jaago, Tiiu (koost). Pärimuslik ajalugu. Tartu: Tartu Ülikooli Kirjastus, lk 27-40.

Timonen, Senni 1990. Orjatar, ruhtinatar ja vapauden ongelma. Naisten omaelämäkerralliset laulut Inkerissä ja Siperiassa. Nenola, Aili \& Timonen, Senni (toim). Louhen sanat. Kirjoituksia kansanperinteen naisista. Helsingi: Suomalaisen Kirjallisuuden Seura, lk 189-208.

Titon, Jeff T. 1980. The Life Story. The Journal of American Folklore 93 (369), lk 276-292 (doi: 10.2307/540572).

Tuisk, Astrid 2011. Olli orja sääl koskil ... Orja- ja vabadustemaatika Siberi eestlaste väljarändamisjuttudes. Acta Historica Tallinnensia 17, lk 55-71 (http://www.kirj.ee/ public/Acta_hist/2011/issue_2/acta-2011-17-55-71.pdf - 22. mai 2018). 
Voolaid, Kalle 2001. Jõumehe fenomen. Georg Lurich ajaloolisest tegelasest rahvajutu kangelaseks. Jaago, Tiiu (koost). Pärimuslik ajalugu. Tartu: Tartu Ülikooli Kirjastus, lk 183-194.

\section{Summary}

\section{Life story from the folkloristic point of view}

\section{Tiiu Jaago}

\section{Assistant Professor}

Department of Estonian and Comparative Folklore

Institute of Cultural Research, University of Tartu

tiiu.jaago@ut.ee

Keywords: folklore, history of Estonian folkloristics, life story, thematic narrative

Research of present-day life stories is multidisciplinary. At the same time, life story research is also disciplinary - the analysis of life stories supports, more or less, the specific features of one or another historically evolved discipline, developing it further.

The Estonian folkloristic life story research is associated with literary science and history as well as ethnology. Folkloristics and literary science share a common interest in the narrative. However, they are different in how life narratives are related to other texts: while literary science relates life stories with writing genres, such as autobiography, life writing, memories, and biographical fiction, in folkloristics life story is connected with concepts like, for example, thematic narrative and personal experience story. In addition to coherent life story texts, folkloristics also studies stories that have been presented in different genres or as single episodes (for example, associating nightmares with everyday or historical events).

Folkloristics is related to the ethnological research of life stories through shared interest in performance. However, while folklorists are primarily interested in how the narrating situation influences text creation, ethnologists are interested in the connection between the narrators' and the public discourses.

The article introduces the evolution of life story research over the 20th century, drawing on the example of Estonian folkloristics. It shows that first there was a deepening interest in narrating real-life characters and in the biographies of folk singers and story-tellers (starting in the 1920s-1930s). During the same period, researchers started to distinguish between stories according to whether the described experience was mediated or first-hand. In the former case, the main character in the story was another person, maybe unknown, but in the latter case, the story concerned an event in which the narrator (i.e. first-person character) was involved. Nevertheless, folklorists were more interested in the storyline than the first-person character's point of view. The first studies in which the narrated plot and the first-person character's experience were viewed as an integrated whole were published in the $1970 \mathrm{~s}$. The new approach did not employ earlier research methods (those based on the plot of the story) but, rather, broadened the ways and possibilities of folkloristic narrative research at the end of the 20 th century and today. 